\title{
Multimode nonlinear simulation technique having near-linear scaling with mode number in circular symmetric waveguides
}

\author{
Lægaard, Jesper
}

Published in:

Optics Letters

Link to article, DOI:

10.1364/OL.398412

Publication date:

2020

Document Version

Publisher's PDF, also known as Version of record

Link back to DTU Orbit

Citation (APA):

Lægaard, J. (2020). Multimode nonlinear simulation technique having near-linear scaling with mode number in circular symmetric waveguides. Optics Letters, 45(15), 4160-4163. https://doi.org/10.1364/OL.398412

\section{General rights}

Copyright and moral rights for the publications made accessible in the public portal are retained by the authors and/or other copyright owners and it is a condition of accessing publications that users recognise and abide by the legal requirements associated with these rights.

- Users may download and print one copy of any publication from the public portal for the purpose of private study or research.

- You may not further distribute the material or use it for any profit-making activity or commercial gain

- You may freely distribute the URL identifying the publication in the public portal

If you believe that this document breaches copyright please contact us providing details, and we will remove access to the work immediately and investigate your claim. 


\section{Optics Letters}

\section{Multimode nonlinear simulation technique having near-linear scaling with mode number in circular symmetric waveguides: publisher's note}

JESPER LAEGSGAARD

DTU Fotonik, Department of Photonics Engineering, Technical University of Denmark, Ørsteds Plads 343, DK-2800 Kongens, Lyngby, Denmark (jlag@fotonik.dtu.dk)

Received 28 August 2020; posted 28 August 2020 (Doc. ID 408794); published 15 September 2020

This publisher's note contains a corrections to Opt. Lett. 45, 4160 (2020). (c) 2020 Optical Society of America https://doi.org/10.1364/OL.408794

In Ref. [1], the author's surname was incorrect as originally published and should have been "Lægsgaard." The article was corrected online on 1 September 2020.

\section{REFERENCE}

1. J. Lægsgaard, Opt. Lett. 45, 4160 (2020). 